\title{
Tidsskriftspublicering og forskningsevaluering
}

\author{
Af Heine Andersen
}

\section{Indledning}

Det specielle hjørne af debatten om forskningsevaluering, jeg vil belyse i mit indlæg, er betydningen af publicering, og herunder specielt publicering $i$ tidsskrifter $\mathrm{i}$ forhold til forskningsprocessen som helhed. Gennem flere år er der foregået en kraftig udvikling i bibliometriske metoder, ledsaget af en omfattende debat om deres anvendelsesmuligheder og begrænsninger. På trods - eller måske snarere på grund - af udviklingens omfang og tempo har der imidlertid været en tendens til at forflygtige nogle helt elementære spørgsmål, der trænger sig på, når publikationstællinger og andre bibliometriske metoder inddrages i forskningsevalueringer: hvad er kriterier for god publiceringspraksis, og hvordan kan sådanne kriterier begrundes?

En stor del af debatten om bibliometriske metoder i forskningsevaluering har været reduktionistisk $\mathrm{i}$ den forstand, at den har drejet sig om, hvorvidt der kan konstrueres kvantitatve udtryk, der generelt gør det muligt at rangordne forskningsenheder eller forskningsresultater efter deres værdi. Den bæren- de idé har i høj grad været at søge efter - mere eller mindre sofistikerede - kvantitative udtryk, således at man kan sige »jo større, jo bedre«.

En slående illustration på det mindre sofistikerede fik vi fornylig i en stort opsat artikel i Weekendavisen (d. 2.5. 1996), der handlede om de igangværende evalueringer af dansk forskning indenfor nationaløkonomi og statskundskab. Den tog udgangspunkt $i$ en baggrundsrapport om statskundskab, spækket med oplysninger, der inklusive tabeller fylder mere end 300 sider. Avisartiklen nævnte dog kun een oplysning fra rapporten: at forskerne i gennemsnit publicerede 4 publikationer pr år. Overskriften på artiklen lød: »Stor ekspert lille forskning «. Det man skal hæfte sig ved her, er ikke så meget journalistens uvidenhed om, at tallet 4 faktisk snarere er usædvanligt højt, som dette, at det netop er dette ene tal, journalisten har selekteret ud af rapportens mange hundrede enkeltoplysninger.

De synspunkter, jeg vil fremlægge i det følgende, er ganske enkelt, at når man ser på, hvad god publicering i forskning er, må man for det første tage udgangspunkt $i$, hvilke funktioner publicering, her- 
under specielt tidsskriftspublicering, der ofte tillægges en særlig betydning, har for forskningens udvikling som helhed, og for det andet, at der i så henseende (som i flere andre) er forskelle mellem fag og forskningsområder, som der må tages hensyn til.

\section{Publiceringens funktioner}

Ofte tales der som om, det der er forskningens egentlige mål, er at publicere. Det kan forekomme både blandt forskere og blandt forskningens eksterne interessenter og publikum, og der kan være forståelige grunde til det. Publicering er den aktivitet, hvorved resultaterne fra forskningsindsatsen bliver synlige for en lidt større omverden, mens en stor del af det, der iøvrigt foregår i forskningen er meget lidt synligt. Derfor er der grund til at slå fast, at forskningens formål ikke er at publicere; det er at producere ny viden. Publicering er ikke et mål i sig selv, den har kun en afledt værdi i kraft af de funktioner, den har $\mathrm{i}$ forskningsudviklingen i det hele taget. At betragte publicering som målet er derfor at foretage en målforskydning, at forveksle et middel med et mål.
For at illustrere dette bringer jeg i tabel 1 nogle tal vedrørende forskeres tidsanvendelse fra en netop gennemført interviewundersøgelse blandt ca. 800 danske forskere indenfor samfundsvidenskaber, datalogi, fysik og medicin. Undersøgelsens er foregået med støtte fra Statens Samfundsvidenskabelige Forskningsråd, og interviewingen er gennemfort af Socialforskningsinstituttets interviewere i slutningen af $1995 \mathrm{og}$ begyndelsen af 1996. Resultaterne er endnu ikke færdiganalyseret, men en oversigtsrapport forventes udsendt efterår 1996, hvori der redegøres nærmere for den anvendte metode, herunder udvælgelse af svarpersoner, interviewskema mv. Der er her tale om foreløbige resultater.

Tabel 1 viser, hvor stor en andel af den sidste samlede arbejdsuge inden interviewet, forskerne i de forskellige fag anvendte til skrivning og redigering af tekster med relation til forskning. Der er her kun medtaget forskere ved universiteter og læreanstalter, ialt 609 personer.

Tabel 1. Andel af samlet tidsforbrug, som danske forskere inden for udvalgte fag anvendte til skrivning $\mathrm{i}$ ugen før interviewtidspunktet. Gennemsnitstal.

\begin{tabular}{|l|c|c|c|}
\hline & $\begin{array}{c}\text { Skrivning i \% } \\
\text { af tidsforbrug }\end{array}$ & Arbejdstimer i ugen ialt & Antal forskere \\
\hline Erhvervsøkonomi & $14 \%$ & 45 & 69 \\
Jura & $22 \%$ & 46 & 49 \\
Nationaløkonomi & $19 \%$ & 48 & 68 \\
Politologi & $25 \%$ & 50 & 28 \\
Sociologi & $21 \%$ & 49 & 32 \\
Andet fag & $17 \%$ & 48 & 21 \\
Tværfaglig & $13 \%$ & 48 & 209 \\
Datalogi & $17 \%$ & 48 & 67 \\
Fysik og medicin & $14 \%$ & 50 & 65 \\
\hline Alle fag & $16 \%$ & 48 & 608 \\
\hline
\end{tabular}


Man ser, at en gennemsnitlig arbejdsuge er på 48 timer for disse 608 forskere. Heraf blev der i gennemsnit anvendt $16 \%$ af tiden til at skrive forskningstekster $\mathrm{i}$, altså mindre end en dag om ugen. Man skal være opmærksom på, at der her er tale om alle typer af forskningsrelaterede tekster, dvs. også f.eks. konferencepapers og arbejdspapirer til mere internt brug, der ikke kommer ud til en større offentlighed. Dernæst fremgår det, at der er meget betydelige forskelle mellem fagene med hensyn til, hvor stor andel af tiden, der anvendes til skrivning, varierende fra 13-14\% i nogle fag (fysik, medicin, erhvervsøkonomi og tværfag) til $21-25 \%$ (sociologi, jura og politologi), altså næsten det dobbelte. Disse forskelle skal formodentlig hovedsageligt forklares ved selve arten og karakteren af den forskning, der er tale om, idet der er store forskelle med hensyn til, i hvor høj grad selve skrive- og formuleringsprocessen er integreret med frembringelsen af ny viden (»at finde ny viden ved at skrive « vs. »at finde ny viden, og derefter nedskrive《). Desuden kan det spille en rolle for tidsforbruget, hvor formaliseret eller kodificeret det er muligt at gøre formen, når resultaterne skal fremstilles skriftligt.

\section{Publicering og sociale normer i forskningen}

Men generelt gælder altså, at publiceringen må betragtes som et middel, hvis betydning og ønskværdige egenskaber derfor er afledt af dens funktioner for forskningen. Disse funktioner $\mathrm{i}$ forskningens udvikling er især belyst indenfor videnskabssociologien, og navnlig i traditionen fra Robert K. Merton har man anvendt et funktionelt perspektiv i analyserne. Sådanne funktionsanalyser tager udgangspunkt $i$ ideer om videnskabers immanente mål og deres rolle i samfund og kultur $\mathrm{i}$ bred forstand. Forskningens institutioner, normer og sociale organisering analyseres derpå $i$ henseende til, hvorledes de fremmer eller hæmmer realiseringen af disse overordnede mål.

Videnskab er i sociologisk forstand i eminent grad en kollektiv aktivitet, og det er her, publiceringsinstitutionen har sin primære funktion. Al ny erkendelse bygger på tidligere indhøstet viden, og det gælder også, selvom forskningen ofte udføres som en individuel, til tider måske ligefrem socialt isoleret aktivitet. Dette kollektive aspekt fremtræder klart i Mertons såkaldte CUDOS-normsæt, som han har hævdet er en sammenfatning af moderne videnskabs grundlæggende etos:

- communism, at ny erkendelse er kollektivt ejet,

- universalism, at resultater skal vurderes ud fra universelle standarder,

- disinterestedness, at private, personlige interesser skal holdes ude ved vurdering af resultater - organized scepticism, at nye resultater ikke skal tages for gode varer, før de har været underkastet en organiseret, kollektiv efterprøvning.

Det er indlysende, at dette kollektive element forudsætter, at resultaterne er offentligt tilgængelige, og det er i dette perspektiv, at publiceringen har sin grundlæggende funktion i forskningsudviklingen. Det er herfra, man kan udlede den grundlæggende norm om, at resultater bør publiceres så snart de foreligger, og at de bør publiceres så fyldestgørende og redeligt som muligt. De overordnede, videnskabsinterne funktionelle krav, der herved tilgodeses er følgende to:

1. Det bliver muligt for andre at efterprøve og kontrollere resultaterne.

2. Resultaterne bliver kollektiv ejendom, så de kan udnyttes af andre $\mathrm{i}$ den videre forskningsudvikling.

I det større perspektiv har publicering naturligvis også den funktion, at resultaterne bliver tilgængelige for befolkningen i almindelighed, således at de kan bidrage til uddannelse (hermed også rekruttering af nye forskere), almindelig oplysning og praktisk anvendelse af resultaterne.

Det er klart, at kravet om hurtig, redelig og fyldestgørende publicering kan og må specificeres og elaboreres yderligere med hensyn til form, rammer og 
medier for publicering. Ud fra det funktionelle syn må man f.eks. umiddelbart sige, at det er dårlig praksis at publicere resultater, som før har været publiceret, eller hvis gyldighed er usikker. Der er et betydeligt skønselemet, når det skal afgøres om resultater er modne og værdige til publicering. Det har hidtil også været dårlig tone (som man dog nu ser overtrådt hyppigere og hyppigere), $i$ hvert fald inden for grundvidenskabelig forskning, at offentliggøre nye resultater $\mathrm{i}$ massemedier, for de har været bragt $\mathrm{i}$ videnskabelige tidsskrifter. Den funktionelle begrundelse har været, at den korte og overfladiske massemedieform ikke muliggør en kollegial, videnskabelig kontrol af resultaterne. Det bryder altså med en norm om kollegial vurdering og organiseret skepticisme.

Ligeledes må publiceringsnormer tage hensyn til relevante målgrupper, deres behov og forudsætninger. Det traditionelle billede af (natur-) grundvidenskaber er tilbøjelig til at give højest prioritet til publicering, der primært er rettet til specialiserede fagkolleger og at betragte formidling til almen offentlighed, studerende eller brugere som værende uden for den egentlig videnskabelige aktivitet eller $i$ hvert fald give den en sekundær plads. Det er imidlertid klart, at målgruppestrukturen kan variere meget mellem discipliner og områder, f.eks. afhængigt at specialiseringsstruktur, og at prioriteringen må være anderledes på anvendelsesorienterede områder end på rent grundvidenkabelige. Typiske målgrupper kan være:

- andre forskere inden for eget speciale

- forskere generelt indenfor faget

- studerende

- evt. professionelle, praktiske udøvere af faget

- potentielle brugere $\mathrm{i}$ almindelighed

- offentlighed i almindelighed

Ud over identifikation og prioritering mellem målgrupper leder det funktionelle analyseperspektiv frem til flere andre relevante spørgsmål vedrørende publicering. Det drejer sig om egnetheden af selve mediestrukturen, bl.a. med hensyn til specialise- ringsgrad og -princip, internationaliseringsgrad, den mest hensigtsmæssige form, og hensigtsmæssig grad af redundans (publicering af det samme forskellige steder og $\mathrm{i}$ forskellige former).

Et yderligere perspektiv, der åbner sig yed det funktionelle perspektiv er muligheden for at identificere funktionelle og disfunktionelle mekanismer i publiceringsinstitutionen. F.eks. vil man forvente, at et meget stærkt publiceringspres vil kunne blive disfunktionelt på flere måder. Det kan fremme tilbøjelighed til prematur publicering, gentagne publiceringer af det samme og til uhensigtsmæssig udparcellering af sammenhængende resultater (i »SPU« (eller LPU)-enheder, smallest (least) publishable unit) på bekostning af kvalitet og overskuelighed. Ligeledes kan man risikere, at kommercialiserede (typisk: anvendelsesorienterede) områder vil være tilbøjelige til at priorietere aftagerorienterede medier for højt til skade for den kollegiale kommunikation og kritik.

\section{Tidsskrifter som videnskabeligt medie}

Det er i mange fag almindeligt at lægge særligt stor vægt på videnskabelige tidsskrifter som det bedste medie til publicering af resultater. $\gg$ Det videnskabelige tidsskrift« som medie for videnskabelig kommunikation, der er blevet etableret og udviklet med forbillede i Philosophical Transactions, udgivet siden 1660 af Royal Society i London, regnes pr. tradition ofte som det egentlige forum for videnskabelig publicering. Det indiceres ved, at der er et særligt prestigehierarki blandt tidsskrifter, og at publicering i disse ofte betragtes som i særlig grad meriterende, sammenlignet med andre former. En god illustration fik vi, da en arbejdsgruppe under undervisningsministeriet for nogle år siden skulle give et forslag til, hvilke nøgletal, der kunne bruges til at sammenfatte forskningsindsatsen. Et forslag var antallet af forskningspublikationer, kategoriseret efter medie, således at artikler $\mathrm{i}$ videnskabelige tidsskrifter blev rangeret højest (Arbejdsgruppe under Undervisningsministeriet 1993. Arbejdsgruppens forslag er dog aldrig blevet implementeret). 
Anlægger vi det funktionelle perspektiv, må man naturligvis stille det spørgsmål, om der er gode grunde hertil, f.eks. ved at tidsskrifter er mere effektive end andre publiceringsmåder til at opfylde de mål, forskning er styret af. Her vil man som regel pege på to manifeste fordele:

- effektiv forhåndsvurdering inden publicering

- større overskuelighed, der letter søgning og gensøgning af resultater.

Den første egenskab hænger sammen med de etablerede referee-systemer, der findes ved videnskabelige tidsskrifter. De indebærer, at artikler inden optagelse bedømmes af fagkyndige, der er specialister på artiklens emne. Det indebærer den fordel, at læsere făr større sikkerhed for, at indholdet er rigtigt. Den anden egenskab fremkommer, hvis der findes en nogenlunde fast specialiseringsstruktur blandt forskere og målgruppe, som afgrænser tidsskrifternes indhold, således at læserne ved fast at følge med $i$ et begrænset antal tidsskrifter kan være sikre på at være godt orienteret om nye resultater, og vide, hvor det er relevant at søge efter tidligere resultater. Overskueligheden styrkes endvidere af de stramme og standardiserede krav, der sædvanligvis findes vedrørende artiklernes omfang og form.

Ud over disse manifeste funktioner er der også blevet peget på nogle latente funktioner af tidsskrifter, som ud fra visse synsvinkler kan være gavnlige. Den første fremkommer ved, at videnskabelige tidsskrifter ofte med tiden bliver rangordnet $i$ et almindeligt kendt prestigehierarki. Hvis dette hierarki faktisk afspejler, hvor betydningsfulde og værdifulde indholdet $\mathrm{i}$ artiklerne typisk er, kan det give en tempofordel ved litteratursøgning. Eftersom tidsskrifternes prestige kan overføres til forfatterne, kan det yderligere have den (gavnlige) funktion at give motivation for forskerne til at konkurrere om optagelse $i$ de berømte tidsskrifter og på den måde understøtte og opretholde forskningens kvalitetsnormer.

Omvendt kan der imidlertid også peges på nogle mulige disfunktioner ved anvendelse af de specialiserede videnskabelige tidsskrifter som publice- ringsform. Dels er der nogle rent teknisk bestemte begrænsninger, nemlig den lange produktionstid og risiko for flaskehalse og kapacitetsknaphed. Kapaciteten er naturligvis relativ $i$ forhold til den helt elementære egenskab ved resultaterne, hvor meget plads der kræves for at trykke dem. Det er således almindeligt kendt, at der er betydelige forskelle mellem hovedfagområder med hensyn til anvendelse af forskellige publiceringsformer, hvilket jeg vil vende tilbage til nedenfor.

Erfaringer viser, at der ved mange tidsskrifter kan gå fra et til to år fra indsendelse til offentliggørelse af en artikel. Det skyldes dels selve den tunge procedure med bedømmelse, redaktionel behandling og udvælgelse af artikler, således at der let opstår ventetider og kødannelse. Dertil kommer, at det kan tage meget lang tid at tilpasse kapaciteten og specialiseringsstrukturen, hvis der sker ekspansion på et felt, eller hvis grænser ændres eller helt nye felter eller specialer dukker op. Det kan medføre, at nogle resultater fra nye og ekspansive områder, der måske er meget banebrydende, har svært ved at finde plads i de etablerede tidsskrifter.

Det leder frem til andre, socialt betingede typer af disfunktioner. Blandt disse kan især nævnes risici for konservatisme, elitestyring og fejlbedømmelser. Naturligt nok vil det typisk være sådan, at sammensætningen af redaktioner og bedømmer-paneler er påvirket af inertiens lov. De rekrutteres som regel på grundlag af fordums fortjenester, og ofte tidsubegrænset. Dette kan medføre, at nye og måske kontroversielle resultater kan have svært ved at finde plads i tidsskrifter. Det er nærliggende at antage, at det især gælder indenfor fag eller områder, hvor der er store uenigheder om fundamentale antagelser, videnskabssyn eller metodeprincipper. Trods de ubetvivlelige fordele, der ligger i den forhåndsbedømmelse, der foregår $\mathrm{i}$ kraft af tidsskrifternes referee-ordninger, kan de også indebære en risiko for fejlbedømmelser, der kan være vanskelige at opfange og korrigere. Reelt er der jo tale om en form for forhåndscensur, der kan være vanskelig af kontrollere, idet sådanne forhåndsbedømmelser som regel foregår meget lukket; herved vanskelig- 
gøres naturligvis den gensidige kollegiale kontrol, den organiserde skepticisme i dette led. Som regel anvendes også anonyme referees, hvilket har fordele, men også den ulempe, at forfatterne har meget begrænsede muligheder for indflydelse og appel, hvis de er uenige i bedømmelserne.

\section{Betydningen af forskellige publiceringsformer på forskellige fagområder}

Det er velkendt, at det navnlig er naturvidenskaber og medicin, til dels også tekniske fag, der anvender tidsskrifter som publiceringskanal, mens især humaniora, men også de fleste samfundsvidenskabelige fag i langt større udstrækning benytter bogformen til publicering. I naturvidenskabelige fag og medicin er det almindeligt, at nye resultater først udkommer i tidsskrifter, og derefter eventuelt senere integreres i lærebøger, mere populariserende samlede fremstillinger mv. I mange samfundsvidenskabelige og humanistiske fag er det langt mere udbredt, at de banebrydende resultater udkommer i bøger. Indenfor et fag som sociologi (som er det, jeg kender bedst) findes mange af de væsentligste resultater slet og ret kun $\mathrm{i}$ (ofte meget tykke) bøger. Det gælder navnlig på teoretiske områder, og som illustration er det $\mathrm{i}$ virkeligheden vanskeligt at komme i tanker om ret mange tidsskriftsartikler af de betydeligste teoretikere som f.eks. Talcott Par- sons, Jürgen Habermas, Pierre Bourdieu eller Anthony Giddens, der har haft betydning for deres store indflydelse i deres fag.

Der findes flere indikatorer på disse forskelle. En af dem er slet og ret at se på opgørelser over, hvor forskere fra forskellige fag publicerer, hvoraf der foreligger flere. Tabel 2 viser tal herfor fra min egen, tidligere omtalte undersøgelse blandt danske forskere.

Publicering i bøger omfatter her såvel egne bøger, medforfatterskab og forfatterskab til enkelte kapitler $i$ antologier o.l. Man ser, at fysikere og medicinere publicerer langt mindre i bøger end forskere fra de samfundsvidenskabelige fag, og til gengæld langt hyppigere $\mathrm{i}$ artikelform. Men man ser samtidig, at der også er ganske store forskelle mellem samfundsvidenskaberne indbyrdes, idet økonomerne ser ud til at skrive mindre $i$ bøger end andre samfundsvidenskabelige forskere; navnlig juristerne er flittige til at benytte bøger.

En anden indikator, der klart indicerer forskelle $\mathrm{i}$ forskellige mediers betydning er citationstællinger. En norsk undersøgelse blandt nordiske forskere viste, at $40-67 \%$ af referencerne i samfundsvidenskabelige artikler var til bøger, mens kun $4 \%$ af referencer i bioteknologi var til bøger (Sivertsen 1993, s. 18f). En tidligere amerikansk undersøgelse

Tabel 2. Danske forskeres publicering i bøger og i tidsskrifter 1994+1995. Interviewundersø்gelse.

\begin{tabular}{|l|c|c|c|}
\hline Forskningsfag & \multicolumn{2}{|c|}{$\begin{array}{c}\text { Antal publilkationer pr. forsker i: } \\
\text { Bøger }\end{array}$} & Antal forskere \\
\hline Erhvervsøkonomi & 1,3 & 1,8 & 80 \\
Jura & 3,7 & 4,0 & 57 \\
Nationaløkonomi & 1,5 & 1,9 & 93 \\
Politologi & 2,5 & 2,4 & 30 \\
Sociologi & 2,1 & 2,3 & 40 \\
Andet fag & 2,1 & 1,5 & 27 \\
Tværfaglig & 1,8 & 1,8 & 261 \\
Datalogi & 1,0 & 1,1 & 81 \\
Fysik og medicin & 0,8 & 6,4 & 72 \\
\hline Alle & 1,7 & 2,5 & 740 \\
\hline
\end{tabular}


fandt helt tilsvarende forskelle - $71 \%$ af referencerne var til bøger i samfundsvidenskabelige artikler mod kun $18 \%$ i naturvidenskaber (Meadows 1974, s. 90).

\section{Mulige forklaringer på forskelle mellem fag}

Den væsentligste grund til disse markante forskelle er uden tvivl af kognitiv art. F.eks. er det indlysende, at resultater, der kan sammenfattes i formler eller statistiske tabeller, fylder mindre end resultater $i$ verbal form. Ligeledes er det indlysende, at kommunikation inden for områder, hvor der er høj grad af standardisering og konsensus vedrørende begrebers betydning, prioritering af problemer og vedrørende relevans og korrekt anvendelse af metoder, kan lade langt mere være underforstået, og derfor kræver mindre plads, end på områder, hvor det modsatte er tilfældet. Dette afspejler sig jo helt tydeligt i de manifeste og i og for sig banale forskelle i fremstillingsform. De fyldige redegørelser for relationer til tidligere forskning og resultater, begrundelser for valg af problemstillinger og begreber, argumentation for fortrin og begrænsninger ved forskellige metoder, alternative muligheder i tolkninger af resultater osv. er velkendt for alle, der læser samfundsvidenskabelig og humanistisk litteratur.

Der findes dog også delområder indenfor samfundsvidenskabelige fag, f.eks. indenfor matematisk økonomi, der nærmer sig den kognitive struktur i mere eksakte fag, og som derfor også i højere grad egner sig til tidsskriftspublicering.

Ud over disse grundlæggende kognitive træk ser det imidlertid også ud til, at der er væsentlige forskelle mellem fagene med hensyn til selve tidsskriftskapaciteten. Faktisk ser det ud som om, der er væsentlig mindre kapacitet i samfundsvidenskabelige fag forhold til, hvad der potentielt egner sig til trykning. Tidsskriftskapaciteten i naturvidenskabelige fag og medicin er simpelthen enormt meget større end i samfundsvidenskabelig. F.eks. bringer Physical Review (i sine 6 sektioner) mere end 5000 artikler årligt, mens American Economic Review kun bringer ca. 150 årligt; måler man det i antal artikler i forhold til antal liesere er et rimeligt skøn, at tidsskriftskapaciteten i naturvidenskabelige fag $\mathrm{i}$ hvert fald mindst er 10 gange større end i samfundsvidenskabelige, måske snarere 20 (Andersen og Frederiksen 1995).

En anden indikator på kapacitetsforskelle kan man få ved at se på afvisningsrater i forskellige fag. En undersøgelse, foretaget af L.L. Hargens (1988) viste således, at afvisningsrater i førende tidsskrifter indenfor sociologi, økonomi, politologi og antropologi lå på $82-89 \%$. Det vil altså sige, at mere end 4 ud af 5 indsendte artikler typisk blev afvist. De tilsvarende tal for naturvidenskabelige fag, fysik, kemi og biologi var 17-35\% - altså nærmest den omvendte relation.

Disse resultater kan yderligere understøttes af en undersøgelse blandt redaktioner af tidsskrifter, der viste, at redaktioner af naturvidenskabelige tidsskrifter typisk mente, at det ville skade kvaliteten, hvis de optog flere artikler; de mente altså, at de stort set trykte de artikler, der var gode nok. Omvendt i de samfundsvidenskabelige tidsskriftsredaktioner. Her var vurderingen, at mange af de afviste artikler var gode nok til trykning, men at man kun var interesseret $i$ at udvælge de allerbedste (Cole 1992).

Dette rejser naturligvis spørgsmålet, hvorfor man så ikke udvider tidsskriftskapaciteten i de samfundsvidenskabelige fag, således at den kom til at svare bedre til det potentielle udbud. Jeg kender ikke til undersøgelser, der har forsøgt at give et dokumenteret svar på dette spørgsmål, men en helt elementær forklaringshypotese kan naturligvis opstilles ved at se på markedsmekanismerne, dvs. inddrage også omkostnings- og efterspørgselssiden. Jo mere plads artiklerne kræver, jo dyrere er det at trykke og distribuere dem, og jo mindre afsætningsmarkedet er, jo større bliver stykomkostningerne. Derfor behøver det ikke at være tillokkende at udbyde en større mængde af artikler, selvom deres forskningsmæssige kvalitet er god nok. 
Disse markedsmæssige vilkår er - ud over selve størrelsen og købekraften hos potentielle læsere også påvirket af socialt organisatoriske egenskaber ved fagene. Eftersom tidsskrifter er et medie, der typisk henvender sig til et fast publikum med nogenlunde stabile interesser (preferencer), egner denne form for kommunikation sig bedst til relativt store velintegrerede (også internationalt) forskningsområder, der er relativt autonome i forhold til omverdenen (typisk grundforskning), som har distinkte og stabile grænser, og som er relativt homogene og monolitiske. Jo større fragmentering, jo hurtigere og hyppigere grænseændringer, jo mere påvirkelig fra skift $\mathrm{i}$ omverdensfaktorer, jo hyppigere (mode-)skift i teori- og metodeidealer, jo mindre gunstige er vilkårene for tidsskriftskommunikation.

Desværre findes der (mig bekendt) ikke undersøgelser af disse rent markedsmæssige og organisatoriske forudsætninger for kommunikationsstrukturen i forskellige fag, der er egnede til at efterprove disse hypoteser. I det hele taget er medieinfrastrukturens funktioner og disfunktioner i forskellige fag og de bestemmende mekanismer ikke særligt godt analyseret. Det ville imidlertid efter min vurdering være særdeles gavnligt og forskningspolitisk relevant at få belyst disse emner grundigere.

\section{Sammenfattende bemærkninger}

På grund af den store betydning, som videnskabelig publicering tillægges $\mathrm{i}$ evalueringssammenhæng, er det vigtigt at se bredere på funktioner og disfunktioner af forskellige publiceringsformer, normer for publicering og af egenskaber ved eksisterende medieinfrastruktuer $\mathrm{i}$ forskellige forskningsfag. I stedet for fortrinsvis at søge efter kvantitative udtryk ud fra devisen $» j o$ mere og større, jo bedre«, bør man i højere grad søge efter normer og kriterier for, hvad der er god publiceringspraksis og for, hvorledes man kan forbedre den eksisterende medieinfrastruktur, dens vægtning af forskellige medietyper, dens organisering og virkemåde, vurderet i forhold til forskningens overordnede mål. Dette mål er at frembringe ny viden, ikke at publicere i sig selv.
Det vil indebære, at der f.eks. bør udvikles og betones normer om, at medie og form bør afpasses efter relevante målgrupper, og at der bør foretages en bevidst prioritering af relevante målgrupper. Det vil også indebære normer, der understøtter kvalitet frem for kvantitet - at et mindre antal virkeligt gode publikationer med egentligt nye resultater er bedre end et større antal dårligere og mindre originale, og at resultater, der udgør en naturlig helhed, bør publiceres som en helhed.

Dette er eksempler på normer, som de enkelte forskere og forskningsgrupper selv har mulighed for at påvirke og handle ud fra indenfor de strukturelle rammer, som nu findes på deres områder. Langt vanskeligere er det med hensyn til selve disse strukturelle rammer, eftersom de ikke uden videre kan ændres, selvom der skulle være gode funktionelle grunde til det. F.eks. kan enkelte forskere ikke uden videre etablere nye tidsskrifter eller udvide eksisterende, selvom der er behov for det. Man kan heller ikke regne med at de af sig selv vil indrette sig funktionelt, f.eks. styret af markedets usynlige hånd. Her er der behov for en kollektiv, koordineret indsats, vejledt af dokumenterede analyser.

\section{Litteratur}

Andersen, Heine og Lars Frode Frederiksen 1995: Internationale tidsskrifter i samfundsvidenskaber - myter og realiteter. Samfundsøkonomen, nr. 5, s. 14-22.

Cole, Stephen 1992: Making Science. Cambridge, Mass.: Harvard University Press.

Hargens, Lowell L 1988: Scholarly Consensus and Journal Rejection Rates. American Sociological Review, vol. 53, s. 139-151.

Meadows, A.J. 1974: Communication in Science. London.

Rapport fra arbejdsgruppe vedrørende nøgleoplysninger om forskningen. Universitetsafdelingen, Undervisningsministeriet 1993.

Sivertsen, Gunnar 1993: Nordisk Samfunnsforskning i internasjonale tidsskrifter. København: Nordisk Ministerråd. TemaNord nr. 5.

Heine Andersen, docent, mag.scient.soc., Handelshøjskolen i Kobenhavn 